\title{
EDITORIAL
}

\section{Managing Plant Microbiomes for Sustainable Biofuel Production}

\author{
Kateryna Zhalnina, ${ }^{1, \dagger}$ Christine Hawkes, ${ }^{2}$ Ashley Shade, ${ }^{3}$ Mary K. Firestone, ${ }^{4}$ and Jennifer Pett-Ridge ${ }^{5, \dagger}$ \\ ${ }^{1}$ Environmental Genomics and Systems Biology Division, Lawrence Berkeley National Laboratory, Berkeley, CA \\ ${ }^{2}$ Department of Plant and Microbial Biology, North Carolina State University, Raleigh, NC \\ ${ }^{3}$ The Great Lakes Bioenergy Research Center, Michigan State University, East Lansing, MI \\ ${ }^{4}$ Department of Environmental Science, Policy and Management, University of California, Berkeley, CA \\ ${ }^{5}$ Physical and Life Sciences Directorate, Lawrence Livermore National Laboratory, Livermore, CA \\ Accepted for publication 25 January 2021.
}

\section{ABSTRACT}

The development of environmentally sustainable, economical, and reliable sources of energy is one of the great challenges of the $21 \mathrm{st}$ century. Large-scale cultivation of cellulosic feedstock crops (henceforth, bioenergy crops) is considered one of the most promising renewable sources for liquid transportation fuels. However, the mandate to develop a viable cellulosic bioenergy industry is accompanied by an equally urgent mandate to deliver not only cheap reliable biomass but also ecosystem benefits, including efficient use of water, nitrogen, and phosphorous; restored soil health; and net negative carbon emissions. Thus, sustainable bioenergy crop production may involve new agricultural practices or feedstocks and should be reliable, cost effective, and minimal input, without displacing crops currently grown for food production on fertile land. In this editorial perspective for the Phytobiomes Journal Focus Issue on Phytobiomes of Bioenergy Crops and Agroecosystems, we consider the microbiomes associated with bioenergy crops, the effects beneficial microbes have on their hosts, and potential ecosystem impacts of these interactions. We also address outstanding questions, major advances, and emerging biotechnological strategies to design and manipulate bioenergy crop microbiomes. This approach could simultaneously increase crop yields and provide important ecosystem services for a sustainable energy future.

Keywords: agriculture, metabolomics, metagenomics, microbiome, nutrient cycling, rhizosphere and phyllosphere, soil ecology, yield and crop productivity
${ }^{\dagger}$ Corresponding authors: J. Pett-Ridge; pettridge2@1lnl.gov,

and K. Zhalnina; kzhalnina@lbl.gov

Funding: Funding for this project was provided by the United States Department of Energy Office of Biological and Environmental Research (DOE OBER), Genomic Science Program Sustainable Bioenergy award DE-SC0014079 to the University of California-Berkeley; Lawrence Livermore National Laboratory (LLNL) (SCW1555); and Lawrence Berkeley National Laboratory (LBNL). K. Zhalnina was also supported by the LBNL Microbial Community Analysis and Functional Evaluation in Soils (m-CAFEs) project and a Laboratory Directed Research and Development Program under U.S. DOE contract number DE-AC02-05CH11231. J. Pett-Ridge and C. Hawkes were additionally supported by LLNL's DOE Genomic Sciences Program Biofuels SFA award (SCW1039) and a subaward to North Carolina State University. Work at LLNL was conducted under the auspices of DOE contract DE-AC52-07NA27344. C. Hawkes was additionally supported by the United States Department of Agriculture (USDA) National Institute of Food and Agriculture (NIFA) Physiology of Agricultural Plants (grant number 2017-67013-29207) and USDA Hatch (accession number 1018688). A. Shade acknowledges support from the Great Lakes Bioenergy Research Center, DOE OBER under award number DE-SC0018409, and the USDA-NIFA and Michigan AgBio Research.

The author(s) declare no conflict of interest.

This manuscript has been authored by an author at Lawrence Berkeley National Laboratory under Contract No. DE-AC02-05CH11231 with the U.S. Department of Energy. The U.S. Government retains, and the publisher, by accepting the article for publication, acknowledges, that the U.S. Government retains a non-exclusive, paidup, irrevocable, worldwide license to publish or reproduce the published form of this manuscript, or allow others to do so, for U.S. Government purposes.
Several prospective crops are currently targeted for development of biofuels and bioproducts in the United States and beyond. These include the perennial grasses switchgrass (Panicum virgatum), miscanthus (Miscanthus $\times$ giganteus), big bluestem (Andropogon gerardii Vitman), sugarcane (Saccharum spp.), reed canarygrass (Phalaris arundinacea L.), giant reed (Arundo donax L.), and bamboo (Phyllostachys spp.), as well as energy sorghum (Sorghum bicolor), which can be either annual or perennial (Blanco-Canqui 2016; Cosentino et al. 2018; Robertson et al. 2017; Sanderson and Adler 2008). In addition, short-rotation tree crops such as hybrid poplar (Populus spp.) and willow (Salix spp.) are being considered (Chudy et al. 2019; Frank et al. 2018; Pawar et al. 2018; Stanton et al. 2020). Long-term studies of biomass and ethanol yields suggest that perennial crops require less fertilizer and have greater potential to increase soil carbon (C) but produce somewhat less biomass compared with annuals (Robertson et al. 2017; Roozeboom et al. 2019; Slessarev et al. 2020). As with most crops, yields and input requirements (water, fertilizer, and herbicides) vary greatly depending on soil type and site conditions.

For biofuels crop management to be truly sustainable, it is essential to consider (i) land degradation and whether new cropland is being established, (ii) competition with food crops, (iii) effects on biodiversity, (iv) water and nitrogen $(\mathrm{N})$ fertilizer inputs needed for cultivation, and (v) overall $\mathrm{C}$ balance and effects on greenhouse gas fluxes (Robertson et al. 2017; US DOE 2014). Growing perennial biofuel crops on 
marginal lands - sites with low soil productivity due to poor physiochemical soil properties or climate conditions - could provide a means to avoid negative environmental feedbacks and food-for-fuel concerns while supporting sufficient crop yields (Gelfand et al. 2013; Tilman et al. 2006). A large amount of abandoned agricultural land exists within the United States (approximately 68 to 99 Mha) (Campbell et al. 2013; Zumkehr and Campbell 2013) and worldwide (approximately 385 to 472 Mha) (Campbell et al. 2008). Because the leading bioenergy crop candidates are perennials that tend to have deeper and more extensive root systems, they are typically better able to withstand the environmental stresses at marginal sites, including nutrient-limited, droughty, and eroded soils (Gelfand et al. 2013). In addition, several studies have demonstrated that perennials have positive ecosystem impacts, including increased soil C, improved soil structure, and decreased greenhouse gas emission from agricultural fields (Robertson et al. 2017) (Fig. 1).

To practice sustainable cultivation of bioenergy crops on marginal soils, thoughtful management of beneficial plant-microbe interactions may be a key way to generate reliable biomass production with low to no inputs, while still enhancing key ecosystem services such as $\mathrm{C}$ sequestration and aggregation (Sher et al. 2020; Slessarev et al. 2020), soil fertility, and soil biodiversity (Busby et al. 2017; Cosentino et al. 2018; Sanderson et al. 1996). Increased crop tolerance to drought or nutrient limitation may be linked to microbe-plant $\mathrm{C}$ and nutrient allocation, with implications for soil $\mathrm{C}$ storage and feedstock yields in subsequent growing seasons (Frank et al. 2004). For example, increased $\mathrm{C}$ allocation to root biomass and increased drought tolerance in switchgrass when grown with certain microbial associates (Zan et al. 2001) can lead to increases in soil $C$ and aggregate formation, further enhancing soil fertility and C stability (Bouton 2007; Ghimire and Craven 2011; Sher et al. 2020). In the woody perennial Populus spp., a well-developed panel of fungal and bacterial isolates has been used in both single inoculation and complex community experiments to disentangle plant beneficial microbial functions such as $\mathrm{N}$-fixation and secretion of indole-3-acetic acid (Bible et al. 2016; Cregger et al. 2021; Doty et al. 2009; Henning et al. 2016, 2019; Timm et al. 2016; Weston et al. 2012). However, in these and other bioenergy crops, the

\section{Ecosystem services}

\section{Carbon sequestration}

Greenhouse gas emissions

\section{Biodiversity}

\section{Biomass for energy needs}

\section{Bioproducts}

Phytoremediation

Nitrate leaching and runoff

\section{Water use efficiency}

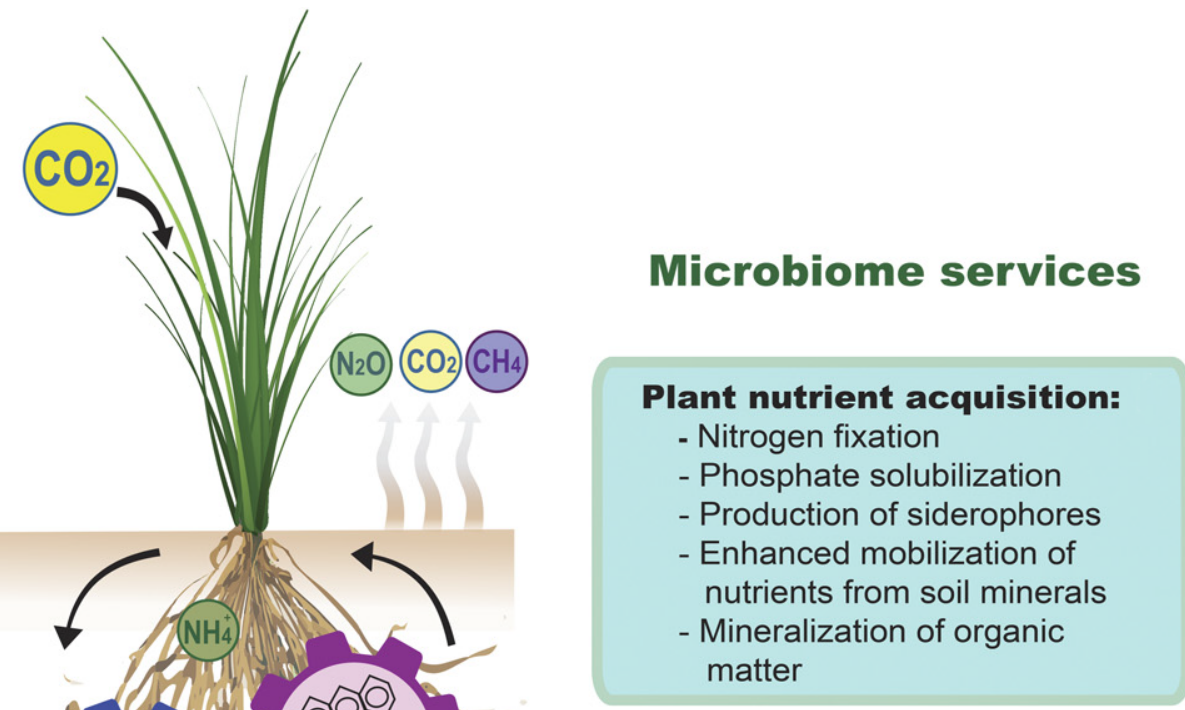

Defense against pathogens: - Production of antimicrobials - Competition for nutrients - Predation on plant pathogens - Interference with quorum sensing affecting virulence - Induced systemic resistance

\section{Drought and salinity stress:} - Production of ACC deaminase - Secretion of osmolytes - Production of plant hormones - Release of antioxidants

Fig. 1. Beneficial microbiomes associated with bioenergy crops can affect plant productivity, health, and stress tolerance, as well as ecosystem services. The blue cog represents metabolites and nutrients exuded by the plant that shape the rhizosphere microbiome. The orange cog represents the plant beneficial microbiome. The purple cog represents metabolites, nutrients, and enzymes produced and released by the rhizosphere microbiome; these influence the host plant and the surrounding environment. 
mechanisms that underlie the compounding effects of beneficial microbial partners are yet to be resolved.

Substantial evidence shows that harnessing beneficial plantmicrobe interactions is a promising strategy to address the needs and challenges of sustainable crop production (Busby et al. 2017; Wallenstein 2017). Beneficial microbial associations with phototrophic organisms date back through geologic time, from the origin of the chloroplast (McFadden 2001) to mycorrhizal associations(Martin et al. 2017) and N-fixing endophytes. Historically, our focus has been on tightly coevolved plant-microbe symbioses; however, plants have evolved with a plethora of microorganisms that support their growth and development. The diverse capabilities of plant-associated microbial communities can lead to improved plant nutrient acquisition, tolerance to environmental stresses, protection against pathogens, and improved seed germination and early plant establishment (Mendes et al. 2011). In return, microbial growth is typically supported by plant resources. For example, plants exude small organic molecules, or metabolites, in the rhizosphere that are used by microorganisms as nutrients, energy sources, or signaling molecules (Pett-Ridge et al. 2021; Zhalnina et al. 2018). Although the balance of "trade" between the plant host and the microbiome has the potential to result in a $\mathrm{C}$ drain for plants, in the marginal soils where bioenergy crops can be sustainably cultivated, these microbes are often beneficial and can be locally adapted (Remke et al. 2020).

In the past century, studies of microbial properties that benefit plant growth and applications of microbial consortia for agriculture have primarily focused on increased food crop yields, while ignoring the many other ecosystem services plant-associated microorganisms provide such as $\mathrm{C}$ sequestration, decreased emissions of greenhouse gases, and improved water quality. Because soil microbiomes largely define plant and ecosystem health, they have the potential to provide an efficient genomic "toolbox" that may be drawn upon by the host or actively manipulated for successful biofuel crop cultivation. This toolbox can simultaneously support plant vigor and increase ecosystem services such as C stability, mitigated $\mathrm{N}$ losses, and increases in overall soil quality (Fig. 1). However, it is important to recognize that some microbiome benefits for plants could have unintended consequences that undermine sustainability at the ecosystem level. For example, enhancing plant stress tolerance by enabling additional water use may facilitate plant growth or reproduction during drought but also deplete water at the system level. Therefore, studies of bioenergy crop-microbiome interaction mechanisms should also consider the effects of those interactions at the ecosystem level.

Harnessing beneficial microbiomes to build stress resilience and optimize biomass production of bioenergy crops on low-nutrient marginal lands is one of the most promising directions for sustainable bioenergy production. However, more research is needed to close major knowledge gaps and link bioenergy microbiome functions and ecosystem services (Table 1). Below, we discuss existing research findings (including articles in the Phytobiomes Journal Focus Issue) that focused on four main topics:

(1) Bioenergy crop microbiomes and the drivers of microbial community assembly

(2) Benefits of microbiomes for bioenergy crops

(3) Potential ecosystem impacts of bioenergy crop-microbiomesoil interactions

(4) Technological advances to understand, design, and manipulate microbial communities for low-input biofuel production

\section{IMPACT OF BIOENERGY CROPS ON MICROBIAL COMMUNITY ASSEMBLY, DIVERSITY, AND COMPOSITION}

To optimize and engineer beneficial plant-microbe interactions for bioenergy crops, it is essential to understand the dynamics of microbial communities in response to different environmental and biotic factors (Arif et al. 2020). Most modern bioenergy crops have been selected due to their high resource use efficiency, high biomass yields, ability to withstand environmental stresses, and potential to enhance $\mathrm{C}$ sequestration, increase soil fertility, and mitigate greenhouse gas emissions (Robertson et al. 2017). Microbial communities of these species may play a significant role in enabling plant survival in adverse environmental conditions such as growth in marginal lands.

To date, the microbiomes of switchgrass, poplar, and miscanthus have been the most extensively studied of the leading cellulosic bioenergy cultivars. The majority of bioenergy crop microbiome studies have used marker genes (16S ribosomal and internal transcribed spacer [ITS]) to characterize bacterial, archaeal, and fungal communities associated with leaves, roots, and soils of bioenergy plants, as well as the different environmental and management factors that affect these microbiomes. Plant compartments, seasonal plant growth, plant ecotypes and cultivars, land management, and soil parameters have all been shown to affect microbial communities of perennial bioenergy crops (Hestrin et al. 2021).

Although soil is a major reservoir for the plant microbiome, plant compartment (endosphere, rhizosphere, phyllosphere, and seed endosphere) is reliably the strongest driver for community assembly in the microbiomes of switchgrass, miscanthus (Cope-Selby et al. 2016; Grady et al. 2019; Li et al. 2015; Singer et al. 2019a, b), sorghum (Gao et al. 2020), and poplar (Cregger et al. 2021, 2018; Timm et al. 2015). For example, in this Focus Issue, Lee and Hawkes (2021) report that fungal communities associated with switchgrass leaves were unique compared with roots and soils, which shared most fungal taxa. Also part of this Focus Issue, a literature review by Hestrin et al. (2021) shows that the switchgrass microbiome is frequently shaped by climate, season, and host genotype. Cregger et al. (2021) discuss similar topics for the poplar microbiome and suggest the importance of studying host and microbial responses in an integrated manner.

A persistent concern for low-input sustainable bioenergy crop cultivation is improving seedling establishment, which makes identification of beneficial microbiomes during plant development an area of particular interest. However, plant requirements at the establishment stage are typically different from adult needs, necessitating an understanding of temporal dynamics. Perennial crops may be more likely to cultivate a beneficial microbiome that persists long-term, whereas annual crops have to reestablish a microbiome from seed in each new growing season. Multiple studies have identified community succession across growing seasons or years, affected by both plant development and metabolism (Beauchamp et al. 2006; Ghimire et al. 2010; Grady et al. 2019). Gao et al. (2020) showed that fungal successional patterns in a single sorghum growing season were strong for leaf, root, and rhizosphere samples. Similarly, initial studies in switchgrass and miscanthus found that Gammaproteobacteria dominated the early phyllosphere microbiome and were replaced by Alphaproteobacteria at later growth stages (Ding and Melcher 2016; Grady et al. 2019). In this Focus Issue, Bowsher et al. (2021) further demonstrate reliable seasonal dynamics of epiphytic phyllosphere fungal communities in switchgrass, and note the prevalence of fungal-bacterial networks in microbiome community assembly. Over a longer time, richness and colonization rates of arbuscular mycorrhizal fungi (AMF) declined from saplings to mature and old-growth Populus-Salix stands (Beauchamp et al. 2006). Temporal variability on longer time scales is also important in grass biofuel crops, as demonstrated by two articles in this Focus Issue: Ma et al. (2021) showed that variation in bacteria communities declined with miscanthus stand age (Ma et al. 
2021), while Lee and Hawkes (2021) found that stand age only played an important role in switchgrass soil fungi, not in leaves or roots (Lee and Hawkes 2021). Additional work is needed to clarify the plant-driven effects of stand age (i.e., photosynthetic capacity of the host plant) versus ecosystem changes that occur as stands mature (i.e., shifts in soil $\mathrm{C}$ or nutrient pools).

Separating environmental selection from other sources of variation in plant microbiomes is a major challenge. In Populus spp., foliar fungal communities varied across 10 sites in the Cascade Mountain Range based on dry versus wet climate conditions, which was more important than geographic distance per se (Barge et al. 2019). Factors such as drought can control microbiome assembly in switchgrass along a rain gradient (Giauque and Hawkes 2013) but drought can also undermine host selection pressure and result in stochastic assembly as observed for sorghum (Gao et al. 2020). In this Focus Issue, Lee and Hawkes (2021) used 14 switchgrass stands across North Carolina to demonstrate that local environmental sorting dominated the assembly of switchgrass fungal microbiomes regardless of plant compartment; however, different soil properties were important for leaves, roots, and soil fungi (Lee and Hawkes 2021). Soil nutrients can also select for the miscanthus microbiome, as demonstrated by Ma et al. (2021), but the effect of fertilization on microbial community composition depended on stand age. In perennial hosts, the direct effects of environmental factors such as nutrients may be moderated by changes in host size or physiology over time.

The interaction of environmental heterogeneity and bioenergy plant ecotypes also creates context-dependency for plant-associated microbiomes. Many plant ecotypes have evolved to succeed under different environmental conditions and exhibit significant phenotypic trait differences that can affect microbiomes (e.g., root architecture) (de Graaff et al. 2013). In poplar, the significant genetic and phenotypic diversity of Populus trichocarpa (due to both outcrossing and hybridization) has allowed detailed comparative studies of the genetic basis of plant-microbe interactions (Martin et al. 2004). This research has established links between specific plant genes and associated microbial genes identified from cultured representatives of the Populus microbial community (Cregger et al. 2021). Similarly, in this Focus Issue, Roley et al. (2021) show that switchgrass lowland cultivars differ significantly from upland cultivars in $\mathrm{N}$ cycling traits, which may be partly related to the plant's recruitment of rhizosphere $\mathrm{N}$ fixers. Overall, plant ecotype seems to influence microbiome composition to a lesser extent relative to other environmental factors (Whitaker et al. 2018); in this Focus Issue, Ulbrich et al. (2021) show that a combination of subtle differences in plant and microbial traits appears to best explain differences in cultivar yields and environmental responses. A better understanding of the variation in the morphological and physiological traits of different bioenergy crop cultivars across environments, and how these traits control plant beneficial microbes, will enable strategies for selection of cultivars that target the specific needs of bioenergy crop production (Roley et al. 2021).

The majority of bioenergy crop soil and microbiome studies have characterized bacterial and fungal communities, while neglecting other significant fractions of plant microbiomes such as protists, microfauna, archaea, and viruses (Hestrin et al. 2021). Protists in particular are known to be important players in soil food webs. They affect plant health (Xiong et al. 2020) by grazing on microbes and releasing inorganic $\mathrm{N}$ that is subsequently taken up by plants (Bonkowski and Clarholm 2012; Clarholm 1985). Through predation of bacteria and fungi, protists and nematodes (microfauna) can reduce bacterial cell numbers by $>50 \%$ and can contribute to $>25 \%$ of available N (Gebremikael et al. 2016; Woods et al. 1982). Microfauna (especially protists) may also act as vectors for viruses, giving them access to new hosts (Geisen et al. 2018). Although viruses are highly abundant and diverse in soils, most current knowledge about the role of viruses comes from aquatic systems; relatively few studies exist on the role of viruses in soil microbiomes and terrestrial biogeochemical cycles (Emerson et al. 2018; Starr et al. 2019; Trubl et al. 2018). Protist grazing can also

TABLE 1

Outstanding questions about bioenergy crop microbiomes

\begin{tabular}{|c|c|}
\hline Topic & Question \\
\hline $\begin{array}{l}\text { Bioenergy crop microbiomes and the drivers of } \\
\text { microbial community assembly }\end{array}$ & $\begin{array}{l}\text { - How does cultivation of bioenergy crops affect microbial community composition, } \\
\text { diversity, and associated microbial processes in rhizosphere? } \\
\text { - How do rhizosphere microbiomes of bioenergy crops cultivated on marginal soils } \\
\text { differ from soils with sufficient nutrients and water availability? }\end{array}$ \\
\hline Benefits of microbiomes for bioenergy crops & $\begin{array}{l}\text { - Can microbiomes be manipulated to build and maintain bioenergy crop productivity } \\
\text { and vigor on marginal lands? } \\
\text { - What are the beneficial microbes and microbial traits that enable survival and } \\
\text { increased yields of bioenergy crops, particularly on marginal soils? } \\
\text { - What are the most efficient land management strategies that support plant and } \\
\text { ecosystem beneficial microbial communities? }\end{array}$ \\
\hline $\begin{array}{l}\text { Potential ecosystem impacts of bioenergy } \\
\text { crop-microbiome-soil interactions }\end{array}$ & $\begin{array}{l}\text { - What are the roles of bioenergy crop-microbe interactions in soil organic matter } \\
\text { turnover and carbon }(\mathrm{C}) \text { sequestration, particularly in marginal soils? } \\
\text { - Could microbial processes affect } \mathrm{C} \text { debt and payback time for bioenergy crops? } \\
\text { - How do plant-microbe interactions affect greenhouse gas }\left(\mathrm{CO}_{2}, \mathrm{~N}_{2} \mathrm{O}, \mathrm{CH}_{4}\right) \text { fluxes } \\
\text { (or sinks) that occur during establishment and cultivation of bioenergy crops and } \\
\text { what are the microbial processes that could help minimize these emissions; for } \\
\text { example, through } \mathrm{C} \text { sequestration? } \\
\text { - What is the role of the microbiome in nutrient cycling of bioenergy crops cultivated in } \\
\text { marginal soils? }\end{array}$ \\
\hline
\end{tabular}

6 Phytobiomes Journal 
select for bacterial populations that are more susceptible to lytic phages, possibly resulting in changes in nutrient release due to phage-induced bacterial lysis (Johnke et al. 2017; Örmälä-Odegrip et al. 2015). Despite their ubiquity and ecological importance in soil functioning, most of the studies addressing microfauna interactions with viruses, bacteria, and fungi have been conducted with only one or very few model species, and almost none exist in bioenergy crops. There is a clear need to understand how bioenergy crop cultivation affects microfauna and virus interactions with the rest of the soil microbiome, as well as biogeochemical processing.

\section{BENEFITS OF MICROBIOMES FOR BIOENERGY CROPS}

The diverse microbial communities associated with perennial biofuel crops can affect host plant productivity, nutrient status, stress tolerance, and survival. Here, we focus on two interactions that could significantly affect sustainable bioenergy crop management: rhizosphere-root microbial communities that affect nutrient access and stress tolerance and leaf-microbe associations that alter plant physiology and stress tolerance. These microbial interactions may be particularly relevant in marginal lands, where limited nutrients, contaminated soils, and infrequent rainfall are common.

Plant-growth-promoting rhizobacteria (PGPR) may benefit plants in multiple ways, by fixing $\mathrm{N}$, solubilizing essential nutrients, producing or moderating plant stress hormones, and producing antibiotics, likely in response to plant root exudates (Ker et al. 2012; Mao et al. 2014). PGPR are found in both the rhizosphere and inside roots of many grasses and trees, including biofuel feedstock species (Bahulikar et al. 2014; Doty et al. 2009; Kirchhof et al. 2001; Li et al. 2015; Rodrigues et al. 2016). For example, PGPR in switchgrass have been shown to enable a $40 \%$ greater yield (Ker et al. 2012) and reduce heavy metal stress (Afzal et al. 2017). In another study, N-fixing PGPR taxa associated with miscanthus resulted in $20 \%$ more seedling biomass compared with uninoculated plants (Straub et al. 2013). Isotopic data confirm that $\mathrm{N}$ fixation occurs in switchgrass rhizosphere soil and on root surfaces (Roley et al. 2019), with higher rates in sites with lower soil N (Roley et al. 2018). Based on nitrogenase (nifH) gene abundance, more $\mathrm{N}$ fixation may occur in soils with low overall fertility but higher iron concentrations; iron is a key cofactor required for nitrogenase function and iron amendment of marginal soils may facilitate additional N fixation (Soman et al. 2018). Optimizing use of beneficial microbial partners may be a particularly critical strategy for bioenergy crops, where there is a greater imperative for sustainable practices and cultivation on suboptimal soils with nutrient or water limitations.

Notably, not all members of the plant microbiome are beneficial; some may have neutral associations or even be opportunistic pathogens. Therefore, there has been much effort to understand the "key" or "core" members of bioenergy crop plant microbiomes (i.e., taxa that are consistently found and tightly associated with the host plant) (Dirks and Jackson 2020; Grady et al. 2019; Revillini et al. 2019). It is essential to recognize that different stages of plant development and growth conditions will have shifts in physiologies that result in different interactions with the immense diversity of microorganisms sustained in soil; therefore, the most beneficial members likely change during plant development and in response to different environmental stressors. Ecological approaches have been applied to rhizobiome survey data (e.g., 16S or ITS) to prioritize the members that are most abundant, most persistent, or deterministically selected by the plant environment (Bowsher et al. 2021; Shade and Stopnisek 2019). Survey approaches fall short in that they do not directly measure function of rhizobiome members.
Correlations found in surveys are not causal and, therefore, cannot prove the importance of any particular microbiome member in itself. However, survey studies identify taxa and species that can be targeted for enrichment, isolation, and synthetic community construction for the next steps to determine whether and under what conditions they benefit the host.

Plant recruitment or targeting of rhizosphere microbiomes that have particular functions may be a strategic way to promote desired plant outcomes, including both productivity and stress tolerance. In sorghum, a crop known for its broad tolerance to drought, salinity, and heat, late-season frost is an important stress. In this Focus Issue, Cloutier et al. (2021) found that sorghum genotypic variation simultaneously influenced rhizosphere microbiome composition and the production of root flavonoid compounds that can serve a protective role under frost stress (Cloutier et al. 2021). Thus, interactions between secondary metabolite chemistry and the root microbiome represent potential adaptations to environmental stressors; recognizing this relationship may enable more efficient selective breeding for frost stress tolerance in sorghum. Similarly, multiple pathways of plant-microbe interaction have been discovered in poplar root associates, including chitin-derived lipochitooligosaccharides and terpenes that mediate mutualistic interactions, small secreted proteins produced by the ecto-mycorrhizal fungal symbiont Laccaria bicolor, and volatile organic compounds and acyl-homoserine lactones that may be involved in interkingdom signaling that benefits the plant host (Cregger et al. 2021).

Root endophytic fungi can have large effects on plant growth, nutrition, and stress tolerance. AMF are the most well-studied root symbionts, and their benefits for switchgrass growth, tillering, and phosphorous (P) uptake in low-nutrient soils have been known for decades (Brejda et al. 1993; Clark et al. 1999; Hetrick et al. 1988). In miscanthus, AMF also enhance nutrient uptake, while protecting plants from heavy metals on contaminated soils (Firmin et al. 2015; Sarkar et al. 2015). Sebacinoid fungi in switchgrass roots also improve seed germination and biomass, likely by scavenging organic forms of N (Ghimire et al. 2010; Ray et al. 2019). In addition, sebacinoid fungi enhance switchgrass drought tolerance by increasing root biomass 100 to $300 \%$ (Ghimire and Craven 2011). As noted earlier, however, the root endophytic microbiome is sometimes more parasitic than beneficial. For example, inoculation with individual dark septate root endophytes led to lower switchgrass root and shoot biomass compared with fungus-free controls, despite biomass benefits for other prairie grasses (Mandyam et al. 2011).

Leaf symbionts are less well studied but appear to be particularly effective mediators of plant physiology and stress responses. Effects on switchgrass growth vary widely among foliar fungal and bacterial isolates (Kleczewski et al. 2012; Xia et al. 2013). Foliar endophytic fungi can double switchgrass plasticity, with variation in plant biomass, water loss, and survival; however, the effects of individual isolates depend on the current environment (Giauque and Hawkes 2013; Giauque et al. 2018). A large number of beneficial endophytes discovered on healthy switchgrass plants growing in a stressful soil habitat were shown to positively affect plant success in subsequent greenhouse trials (Xia et al. 2018). Leaf endophytes may affect plants via phytohormone signaling, production of osmoprotectants, and effects on gene regulation (Farrar et al. 2014). In controlled lab conditions, endophytic bacteria in culture can also affect seedling growth via airborne chemicals (Gagne-Bourgue et al. 2013).

Functional tests of microbial taxa that benefit the plant are typically done one strain at a time, although microbiome diversity in the field can be high and ecological assembly processes will likely be at play in real-world settings. Microbial mixtures may produce positive interactions that result in additive or synergistic benefits to 
the host but, in other cases, mixtures can negate benefits of individual taxa (Schmidt et al. 2019). This diversity of interactions makes predictions in real-world systems challenging. For example, combinations of only two fungal taxa in switchgrass leaves can result in fungal interactions with nonadditive effects on the plant, requiring metrics of fungal niche breadth to predict outcomes (Connor et al. 2017). Similarly, arrival order of fungi on poplar leaves determined both microbiome composition and plant disease susceptibility (Leopold and Busby 2020). These approaches are somewhat hindered by a lack of high-throughput methods. In model systems, modular synthetic consortia are being used to test effects of different groups in complex bacterial communities (Finkel et al. 2020); these modular approaches may more rapidly identify key taxa and interactions in microbiomes.

\section{POTENTIAL ECOSYSTEM IMPACTS}

Collectively, the unique properties of perennial bioenergy plants and the beneficial services provided by their rhizosphere, phyllosphere, and endosphere microbiomes can do more than support sustainable yields for bioenergy purposes; they can also deliver a number of ecosystem services (Fig. 1). In sustainable or low-input bioenergy crop cultivation, mutualistic plant-microbe interactions could be leveraged to simultaneously enhance feedstock yield and soil $\mathrm{C}$ accrual, while also improving nutrient ( $\mathrm{N}$ and $\mathrm{P}$ ) acquisition, tolerance to water stress, and promoting a diverse soil biota. Focusing on these cobenefits can open additional opportunities for microbe-assisted designs of sustainable biofuel feedstock systems (Carvalho et al. 2017; Robertson et al. 2017), and is particularly relevant for marginal soil cultivation.

Most of the vast pool of $\mathrm{C}$ in the terrestrial biosphere is derived from decomposed plant and soil microbial material; the fluxes that control this pool are critical to the global $\mathrm{C}$ cycle. Aboveground biomass provides a temporary $\mathrm{C}$ reservoir until harvest, while belowground $\mathrm{C}$ in root biomass (representing approximately $84 \%$ of total plant biomass and up to $150 \mathrm{~cm}$ of depth for switchgrass) can persist on far longer timescales (Follett et al. 2012; Slessarev et al. 2020). Particularly in marginal lands, where prior land use or erosion may have incurred a large $\mathrm{C}$ debt, the potential for $\mathrm{C}$ accrual with deep-rooted perennial bioenergy crops is high. For example, in southwest Michigan, switchgrass stands on marginal soils had a calculated net greenhouse gas balance of $\mathrm{CO}_{2}-\mathrm{e}$ at $-851 \mathrm{~g} \mathrm{~m}^{-2}$ year ${ }^{-1}$ in unfertilized conditions and $\mathrm{CO}_{2}$-e at $-932 \mathrm{~g} \mathrm{~m}^{-2}$ year $^{-1}$ with added N. More broadly, it is estimated that the acreage available for bioenergy switchgrass cultivated on marginal lands (>15 million ha), would not conflict with food production (Gelfand et al. 2013; Stoof et al. 2014). Roughly $11 \%$ of the U.S. mainland comprises "marginal lands" and represents an untapped agronomic resource well suited to the deep roots and rhizodeposits contributed by perennial grasses (Sher et al. 2020). Inoculation with plantgrowth-promoting or "probiotic" microbial associates can lead to increased root biomass and higher soil $\mathrm{C}$ allocation, further enhancing soil fertility and C stability (Kim et al. 2012; Mau et al. 2015; Sher et al. 2020). As such, cultivation of deep-rooted bioenergy perennials may represent a means to repay the 133-Pg "soil carbon debt" human societies owe to agricultural soils (Sanderman et al. 2017).

Insufficient water availability can reduce bioenergy crop production (Wang et al. 2010), particularly in marginal lands, but some root-associated microbes appear to mitigate the negative effects of drought stress (Gao et al. 2020; Ghimire and Craven 2011; Wipf et al. 2020). In sorghum, Gram-positive bacteria play an outsized role in plant-water relationships (Xu et al. 2018), suggesting that manipulating these taxa could lead to improved crop fitness.
Likewise, in switchgrass, some biofuel cultivars perform better in drought conditions when colonized by the ectomycorrhizal fungus Serendipita bescii than in well-watered conditions when the fungus is absent (Ghimire and Craven 2011; Ray and Craven 2016). AMF-plant associations can also affect plant water needs through the stabilization of soil aggregates, improved plant water retention, and transporting water to the host along mycorrhizal hyphae (Kakouridis et al. 2020). Finally, plant genetics also plays a key role in plant-water balance; certain genetic variants of switchgrass and many varieties of sorghum can produce significant dry matter yield under water-limited conditions (Robins 2012); however, the mechanistic and genetic bases for these differences are not fully understood.

Leveraging mutualistic plant-microbe interactions could lessen the need for fertilizer applications if beneficial associations with soil biota enhance nutrient availability. This could be particularly key to ensuring sustainability goals for $\mathrm{N}$ management, because the application of $\mathrm{N}$ fertilizer has major consequences for global warming potential via nitrous oxide emissions from cropping systems (Robertson et al. 2000; Shcherbak et al. 2014). Switchgrass plants grown with arbuscular or sebacinoid mycorrhizal fungi, or N-fixing bacteria (diazotrophs), generally have higher productivity and improved soil fertility, including in marginal soils (Clark et al. 2005). Because these associations decrease the need for the application of $\mathrm{N}$ fertilizers, they also potentially reduce $\mathrm{N}_{2} \mathrm{O}$ emissions (Fazio and Monti 2011). There has been substantial research dedicated to understanding the associations of these fungal and bacterial groups with their host crop, as well as the host, environmental, and microbial conditions that determine their maximum effectiveness for the plant (Davis et al. 2009; Knoth et al. 2014; Smercina et al. 2019). Articles in this Focus Issue provide further insights regarding these plant-microbe relationships with $\mathrm{N}$ for host, environment, and microbial dimensions.

Roley et al. (2021) show that host genotype and ecotype can drive variation in associative $\mathrm{N}$ fixation potential and $\mathrm{N}$ resorption among high-yielding switchgrass cultivars for rhizosphere soil and root compartments, suggesting a potential for selective breeding of $\mathrm{N}$ efficient switchgrass. Smercina et al. (2021) further demonstrate that the amount of $\mathrm{N}$ available to switchgrass roots can drive changes in root exudation. Because differences in root exudates have been shown to alter rhizosphere microbial community composition for plants more generally (Zhalnina et al. 2018), this suggests that soil $\mathrm{N}$ availability and fertilization can moderate the plant microbiome indirectly via the host plant. Finally, in this Focus Issue, Bahulikar et al. (2021) show that there is an inverse relationship between the levels of nitrogenase activity and associated transcripts of the bacterial diazotroph community versus the amount of fertilizer applied to switchgrass in field conditions; no and low fertilizer treatments had the highest microbial activities. Together, these new results add to the understanding of how to minimize bioenergy crop needs for $\mathrm{N}$ fertilizer by leveraging their engagement with beneficial microbes.

Bioenergy crop access to other nutrients such as $\mathrm{P}$ and $\mathrm{K}$ can similarly benefit from microbiome associations (Bücking and Heyser 2003; Garcia and Zimmermann 2014; Sharma et al. 2013; Toro et al. 1997). Although $\mathrm{N}$ fertilization shows the greatest impact on bioenergy plant growth in many short- to medium-term field studies, over the long term (decades), P fertilization will be required to maintain high yields. Harnessing the plant microbiome could improve $\mathrm{P}$ recycling, retention, and plant bioavailability, while reducing $\mathrm{P}$ runoff associated with fertilizers and dependence on global stocks of mineral $\mathrm{P}$ that are rapidly being depleted (Cordell et al. 2009; Vaccari 2009). Both arbuscular and sebacinoid mycorrhizae can increase $\mathrm{P}$ accessibility to plants by 
extending nutrient absorptive surface area and producing organic acids, siderophores, and extracellular phosphatases (Bücking and Heyser 2003; Shen et al. 2011; Vance et al. 2003). Ectomycorrhizal associates may be particularly important for $\mathrm{P}$ acquisition in poplar. Some bacteria can also improve mycorrhizal colonization of plants (Toro et al. 1997) or directly increase P solubilization (De Bolle et al. 2013), although their performance under in situ conditions is inconsistent (Sharma et al. 2013). However, in multiple switchgrass cultivars, Sawyer et al. (2019) found that microbial community structure was unaffected by $\mathrm{P}$ fertilization. Additional research is needed to establish the role that bioenergy crop microbiomes play in determining the fate of $\mathrm{P}$ and $\mathrm{P}$ availability (Sawyer et al. 2019).

\section{TECHNOLOGICAL ADVANCES AND STRATEGIES TO UNDERSTAND, DESIGN, AND MANIPULATE MICROBIAL COMMUNITIES FOR LOW-INPUT BIOFUEL PRODUCTION}

Microbiome engineering to increase plant biomass and enhance stress resilience represents a promising biotechnological strategy for sustainable bioenergy crop production. Microbiomes that enable plant establishment under suboptimal conditions while improving soil health are particularly important for low-input production systems such as cultivating stress-resilient bioenergy crops on marginal lands.

To efficiently engineer microbiomes for bioenergy crops, we need to move beyond the characterization of plant-growth-promoting properties of microorganisms and focus on understanding the mechanistic basis of how beneficial microbial communities interact with bioenergy crops and ecosystems (Table 1). We encourage combining observations collected at different scales, from millimeterfine-scale controlled lab experiments to extensive field studies. New technologies can help to overcome many challenges in microbiome design and engineering such as niche overlap and nonadditive effect of microbiomes on plant performance (Connor et al. 2017), the small taxonomic diversity of cultivated representatives, lack of knowledge about host specificity, and inability to retain efficacy of bioengineered communities in the field.

Technologies that enable high-throughput microbial cultivation and characterization of diverse bacteria, archaea, fungi, protists, and viruses may be used to improve culturability of rhizosphere organisms, or to characterize and build beneficial, simplified microbial communities for bioenergy crops. For example, a recent study by Cross et al. (2019) used genome-informed antibody engineering and single-cell sequencing for targeted isolation and characterization of uncultivated Saccharibacteria (TM7) (Cross et al. 2019). In addition, microfluidic approaches can significantly improve the cultivation and screening of rare microbial taxa (Kehe et al. 2019; Watterson et al. 2020). Newly optimized protocols for soil virome extractions (Göller et al. 2020) and single-cell viral tagging (Džunková et al. 2019) can lead to the identification of host-phage pairings and incorporation of viruses into bioenergy crop-microbe interaction frameworks. New molecular approaches have been developed to target protists, which have been overlooked for their potential to mediate plant health and biogeochemistry in the rhizosphere (Xiong et al. 2020). All of these approaches enable targeted isolations of rare, previously uncultivated organisms from bioenergy crops and improved design of synthetic communities, and can help disentangle beneficial plant-microbe interactions.

To study bioenergy crop-microbe interactions under controlled conditions, where rhizosphere processes can be tracked in real time, a variety of simplified systems and controlled environments have been developed. These allow dynamic imaging of root colonization by bacteria, collection of plant exudates, characterization of plant phenotypes, precise manipulations of environmental conditions, and analysis of multitrophic complexity (Gao et al. 2018; Grossmann et al. 2011; Henkes et al. 2018; Massalha et al. 2017; Vanderkelen et al. 2020). These controlled environments span multiple scales, from millimeter-scale microfluidic devices (Gao et al. 2018; Grossmann et al. 2011; Massalha et al. 2017) to extensive mesocosms (Vanderkelen et al. 2020) to artificial biospheres (Nelson et al. 2015). These new technologies could be used for mechanistic bioenergy crop microbiome studies, because they enable experiments that dissect the environmental complexity of crop microbiomes and allow researchers to connect lab-identified mechanisms of plant-microbe interactions to field observations.

Measuring community dynamics and identifying active microbes and their functions in the rhizosphere remain challenging. Emerging technologies can specifically target the active fraction in rhizosphere microbiomes of bioenergy crops (Mao et al. 2014). These include stable isotope probing techniques such as ${ }^{13} \mathrm{C}$ PLFA, ${ }^{13} \mathrm{C}$ DNA, mRNA, ${ }^{18} \mathrm{O}$-labeled $\mathrm{H}_{2} \mathrm{O}$, qSIP, SIP viromics, Chip-SIP, and Pro-SIP, summarized by Pett-Ridge and Firestone (2017); metatranscriptomics (Nuccio et al. 2020); bioorthogonal noncanonical amino acid tagging (Couradeau et al. 2019); and spatially resolved gene-expression profiling in single cells (Moffitt et al. 2016). These approaches are particularly useful in situations where the active membership of the plant-microbiome changes in response to stress (Bowsher et al. 2019) or differences in root exudates provided by the plant (Caddell et al. 2020).

Characterization of plant-microbe chemistry is another important aspect of managing plant microbiomes for sustainable biofuel production. Metabolites released by plants and microorganisms are central participants in the "chemical conversations" that drive plant-microbiome interactions. However, we still know little about how plant-exuded metabolites shape microbial communities and how beneficial microbes attracted by exudates can later affect plant phenotypes by producing their own secondary metabolites. Sampling of plant exudates is a major challenge but several sampling techniques now exist, including hydroponic and soil-based approaches, sipping, using suction cups, and microdialysis probes, which have been summarized and discussed by Oburger and Schmidt (2016) and Oburger and Jones (2018). Recent studies have described plant exudate profiles of grasses (Pett-Ridge et al. 2021; Vieira et al. 2019; Zhalnina et al. 2018); however, only a handful of studies have analyzed exudates or root or rhizosphere soil metabolites of bioenergy crops (Cloutier et al. 2021; Smercina et al. 2021; Xu et al. 2018). A better understanding of plant-microbe metabolite "cross-talk" will enable customized engineering of beneficial communities for bioenergy crops by manipulating plant chemistry.

CRISPR-based tools have additional potential to advance our understanding of bioenergy crop-microbe interactions, design synthetic communities, and manipulate native plant microbiomes for agronomic trait improvement (Shelake et al. 2019). Functions that could be manipulated include novel microbial genes and their regulation, modifications of microbial genomes to improve nutrient acquisition (e.g., $\mathrm{N}_{2}$ fixation and $\mathrm{P}$ solubilization) and plant stress resistance (Shelake et al. 2019), and targeted genome editing of microorganisms within their native communities (Rubin et al. 2020). Similarly, CRISPR-based techniques could be used to engineer bioenergy crops with specific phenotypic traits (e.g., production of signaling molecules and altered root morphology) that allow the plant to recruit and efficiently retain beneficial microbes while repelling pathogens. We caution, however, that bioengineering — whether based at the genetic or organism-level—can have unintended consequences; and built-in genetic security mechanisms should be considered in advance. 


\section{CONCLUSIONS}

Cultivation of perennial bioenergy crops on low-fertility marginal lands is a promising strategy for sustainable bioenergy cultivation that can provide the yields needed for efficient biofuel crop production without competing for land currently allocated to food crops. In addition, informed management of plant-microbe mutualisms can increase plant yields while enhancing ecosystem services ranging from $\mathrm{C}$ sequestration to increased soil fertility and promotion of diverse soil communities that are the hallmark of healthy soils. A growing number of studies, including 10 articles published in this Focus Issue, demonstrate perennial crops' ability to provide ecosystem services such as $\mathrm{C}$ sequestration, reduction of greenhouse gas emissions, increased soil fertility, and biodiversity promotion. Beneficial microbial communities of bioenergy crops can enable their successful establishment and cultivation on nutrient-depleted and water-limited marginal lands. However, we still need a better understanding of the dialogue that soil microbiomes establish with their plant hosts under both replete and stressful growing conditions. Integration of advanced technologies provides novel ways to characterize beneficial bioenergy crop microbiomes, identify and visualize rhizosphere chemistry, and manipulate communities for improved agricultural and environmental services.

\section{ACKNOWLEDGMENTS}

We thank the editors of the Phytobiomes Journal for handling manuscripts for this Focus Issue and J. Yusko and J. Cataldo at Lawrence Livermore National Laboratory for assistance with graphic design.

\section{LITERATURE CITED}

Afzal, S., Begum, N., Zhao, H., Fang, Z., Lou, L., and Cai, Q. 2017. Influence of endophytic root bacteria on the growth, cadmium tolerance and uptake of switchgrass (Panicum virgatum L.). J. Appl. Microbiol. 123:498-510.

Arif, I., Batool, M., and Schenk, P. M. 2020. Plant microbiome engineering: Expected benefits for improved crop growth and resilience. Trends Biotechnol. 38:1385-1396.

Bahulikar, R. A., Chaluvadi, S. R., Torres-Jerez, I., Mosali, J., Bennetzen, J. L., and Udvardi, M. 2021. Nitrogen fertilization reduces nitrogen fixation activity of diverse diazotrophs in switchgrass roots. Phytobiomes J. 5:80-87.

Bahulikar, R. A., Torres-Jerez, I., Worley, E., Craven, K., and Udvardi, M. K. 2014. Diversity of nitrogen-fixing bacteria associated with switchgrass in the native tallgrass prairie of northern Oklahoma. Appl. Environ. Microbiol. 80:5636-5643.

Barge, E. G., Leopold, D. R., Peay, K. G., Newcombe, G., and Busby, P. E. 2019. Differentiating spatial from environmental effects on foliar fungal communities of Populus trichocarpa. J. Biogeogr. 46:2001-2011.

Beauchamp, V. B., Stromberg, J. C., and Stutz, J. C. 2006. Arbuscular mycorrhizal fungi associated with Populus-Salix stands in a semiarid riparian ecosystem. New Phytol. 170:369-380.

Bible, A. N., Fletcher, S. J., Pelletier, D. A., Schadt, C. W., Jawdy, S. S., Weston, D. J., Engle, N. L., Tschaplinski, T., Masyuko, R., Polisetti, S., Bohn, P. W., Coutinho, T. A., Doktycz, M. J., and Morrell-Falvey, J. L. 2016. A carotenoid-deficient mutant in Pantoea sp. YR343, a bacteria isolated from the rhizosphere of Populus deltoides, is defective in root colonization. Front. Microbiol. 7:491.

Blanco-Canqui, H. 2016. Growing dedicated energy crops on marginal lands and ecosystem services. Soil Sci. Soc. Am. J. 80:845-858.

Bonkowski, M., and Clarholm, M. 2012. Stimulation of plant growth through interactions of bacteria and protozoa: Testing the auxiliary microbial loop hypothesis. Acta Protozool. 51:237-247.

Bouton, J. H. 2007. Molecular breeding of switchgrass for use as a biofuel crop. Curr. Opin. Genet. Dev. 17:553-558.

Bowsher, A. W., Benucci, G. M. N., Bonito, G., and Shade, A. 2021. Seasonal dynamics of core fungi in the switchgrass phyllosphere, and co-occurrence with leaf bacteria. Phytobiomes J. 5:60-68.
Bowsher, A. W., Kearns, P. J., and Shade, A. 2019. 16S rRNA/rRNA gene ratios and cell activity staining reveal consistent patterns of microbial activity in plant-associated soil. mSystems 4:300003-19.

Brejda, J. J., Yocom, D. H., Moser, L. E., and Waller, S. S. 1993. Dependence of 3 Nebraska Sandhills warm-season grasses on vesicular-arbuscular mycorrhizae. Rangeland Ecol. Manage. 46:14-20.

Bücking, H., and Heyser, W. 2003. Uptake and transfer of nutrients in ectomycorrhizal associations: Interactions between photosynthesis and phosphate nutrition. Mycorrhiza 13:59-68.

Busby, P. E., Soman, C., Wagner, M. R., Friesen, M. L., Kremer, J., Bennett, A., Morsy, M., Eisen, J. A., Leach, J. E., and Dangl, J. L. 2017. Research priorities for harnessing plant microbiomes in sustainable agriculture. PLoS Biol. 15:e2001793.

Caddell, D. F., Louie, K., Bowen, B., Sievert, J. A., Hollingsworth, J., Dahlberg, J., Purdom, E., Northen, T., and Coleman-Derr, D. 2020. Drought shifts sorghum root metabolite and microbiome profiles and enriches the stress response factor pipecolic acid. bioRxiv.

Campbell, J. E., Lobell, D. B., Genova, R. C., and Field, C. B. 2008. The global potential of bioenergy on abandoned agriculture lands. Environ. Sci. Technol. 42:5791-5794.

Campbell, J. E., Lobell, D. B., Genova, R. C., Zumkehr, A., and Field, C. B. 2013. Seasonal energy storage using bioenergy production from abandoned croplands. Environ. Res. Lett. 8:035012.

Carvalho, J. L. N., Hudiburg, T. W., Franco, H. C. J., and DeLucia, E. H. 2017. Contribution of above- and belowground bioenergy crop residues to soil carbon. Glob. Change Biol. Bioenergy 9:1333-1343.

Chudy, R. P., Busby, G. M., Binkley, C. S., and Stanton, B. J. 2019. The economics of dedicated hybrid poplar biomass plantations in the western U.S. Biomass Bioenergy 124:114-124.

Clarholm, M. 1985. Interactions of bacteria, protozoa and plants leading to mineralization of soil nitrogen. Soil Biol. Biochem. 17:181-187.

Clark, R. B., Baligar, V. C., and Zobel, R. W. 2005. Response of mycorrhizal switchgrass to phosphorus fractions in acidic soil. Commun. Soil Sci. Plant Anal. 36:1337-1359.

Clark, R. B., Zeto, S. K., and Zobel, R. W. 1999. Arbuscular mycorrhizal fungal isolate effectiveness on growth and root colonization of Panicum virgatum in acidic soil. Soil Biol. Biochem. 31:1757-1763.

Cloutier, M., Chatterjee, D., Elango, D., Cui, J., Bruns, M. A., and Chopra, S. 2021. Sorghum root flavonoid chemistry, cultivar, and frost stress effects on rhizosphere bacteria and fungi. Phytobiomes J. 5:39-50.

Connor, E. W., Sandy, M., and Hawkes, C. V. 2017. Microbial tools in agriculture require an ecological context: Stress-dependent non-additive symbiont interactions. Agron. J. 109:917-926.

Cope-Selby, N., Cookson, A., Squance, M., Donnison, I., Flavell, R., and Farrar, K. 2016. Endophytic bacteria in miscanthus seed: Implications for germination, vertical inheritance of endophytes, plant evolution and breeding. Glob. Change Biol. Bioenergy 9:57-77.

Cordell, D., Drangert, J.-O., and White, S. 2009. The story of phosphorus: Global food security and food for thought. Glob. Environ. Change 19: 292-305.

Cosentino, S. L., Scordia, D., Testa, G., Monti, A., Alexopoulou, E., and Christou, M. 2018. 1 - The importance of perennial grasses as a feedstock for bioenergy and bioproducts. Pages 1-33 in: Perennial Grasses for Bioenergy and Bioproducts. E. Alexopoulou, ed. Academic Press, Elsevier, London, U.K.

Couradeau, E., Sasse, J., Goudeau, D., Nath, N., Hazen, T. C., Bowen, B. P., Chakraborty, R., Malmstrom, R. R., and Northen, T. R. 2019. Probing the active fraction of soil microbiomes using BONCAT-FACS. Nat. Commun. 10:2770.

Cregger, M. A., Carper, D. L., Christel, S., Doktycz, M. J., Jessy Labbé, M. J., Michener, J. K., Dove, N. C., Johnston, E. R., Moore, J. A. M., Velez, J. M., Morrell-Falvey, J., Muchero, W., Pelletier, D. A., Retterer, S., Tschaplinski, T. J., Tuskan, G. A., Weston, D. J., and Schadt, C. W. 2021. Plant-microbe interactions: From genes to ecosystems using Populus as a model system. Phytobiomes J. 5:29-38.

Cregger, M. A., Veach, A. M., Yang, Z. K., Crouch, M. J., Vilgalys, R., Tuskan, G. A., and Schadt, C. W. 2018. The Populus holobiont: Dissecting the effects of plant niches and genotype on the microbiome. Microbiome 6:31.

Cross, K. L., Campbell, J. H., Balachandran, M., Campbell, A. G., Cooper, S. J., Griffen, A., Heaton, M., Joshi, S., Klingeman, D., Leys, E., Yang, Z., Parks, J. M., and Podar, M. 2019. Targeted isolation and cultivation of uncultivated bacteria by reverse genomics. Nat. Biotechnol. 37:1314-1321.

Davis, S. C., Parton, W. J., Dohleman, F. G., Smith, C. M., Grosso, S. D., Kent, A. D., and DeLucia, E. H. 2009. Comparative biogeochemical cycles of 
bioenergy crops reveal nitrogen-fixation and low greenhouse gas emissions in a Miscanthus $\times$ giganteus agro-ecosystem. Ecosystems (N. Y.) 13:144-156.

De Bolle, S., Gebremikael, M. T., Maervoet, V., and De Neve, S. 2013.

Performance of phosphate-solubilizing bacteria in soil under high phosphorus conditions. Biol. Fertil. Soils 49:705-714.

de Graaff, M.-A., Six, J., Jastrow, J. D., Schadt, C. W., and Wullschleger, S. D. 2013. Variation in root architecture among switchgrass cultivars impacts root decomposition rates. Soil Biol. Biochem. 58:198-206.

Ding, T., and Melcher, U. 2016. Influences of plant species, season and location on leaf endophytic bacterial communities of non-cultivated plants. PLoS One 11:e0150895.

Dirks, A. C., and Jackson, R. D. 2020. Community structure of arbuscular mycorrhizal fungi in soils of switchgrass harvested for bioenergy. Appl. Environ. Microbiol. 86:e00880-20.

Doty, S. L., Oakley, B., Xin, G., Kang, J. W., Singleton, G., Khan, Z., Vajzovic, A., and Staley, J. T. 2009. Diazotrophic endophytes of native black cottonwood and willow. Symbiosis 47:23-33.

Džunková, M., Low, S. J., Daly, J. N., Deng, L., Rinke, C., and Hugenholtz, P. 2019. Defining the human gut host-phage network through single-cell viral tagging. Nat. Microbiol. 4:2192-2203.

Emerson, J. B., Roux, S., Brum, J. R., Bolduc, B., Woodcroft, B. J., Jang, H. B., Singleton, C. M., Solden, L. M., Naas, A. E., Boyd, J. A., Hodgkins, S. B., Wilson, R. M., Trubl, G., Li, C., Frolking, S., Pope, P. B., Wrighton, K. C., Crill, P. M., Chanton, J. P., Saleska, S. R., Tyson, G. W., Rich, V. I., and Sullivan, M. B. 2018. Host-linked soil viral ecology along a permafrost thaw gradient. Nat. Microbiol. 3:870-880.

Farrar, K., Bryant, D., and Cope-Selby, N. 2014. Understanding and engineering beneficial plant-microbe interactions: Plant growth promotion in energy crops. Plant Biotechnol. J. 12:1193-1206.

Fazio, S., and Monti, A. 2011. Life cycle assessment of different bioenergy production systems including perennial and annual crops. Biomass Bioenergy 35:4868-4878

Finkel, O. M., Salas Gonzalez, I., Castrillo, G., Conway, J. M., Law, T. F., Teixeira, P. J. P. L., Wilson, E. D., Fitzpatrick, C. R., Jones, C. D., and Dang1, J. L. 2020. A single bacterial genus maintains root growth in a complex microbiome. Nature 587:103-108.

Firmin, S., Labidi, S., Fontaine, J., Laruelle, F., Tisserant, B., Nsanganwimana, F., Pourrut, B., Dalpé, Y., Grandmougin, A., Douay, F., Shirali, P., Verdin, A., and Lounès-Hadj Sahraoui, A. 2015. Arbuscular mycorrhizal fungal inoculation protects Miscanthus $\times$ giganteus against trace element toxicity in a highly metal-contaminated site. Sci. Total Environ. 527-528:91-99.

Follett, R. F., Vogel, K. P., Varvel, G. E., Mitchell, R. B., and Kimble, J. 2012. Soil carbon sequestration by switchgrass and no-till maize grown for bioenergy. Bioenerg. Res. 5:866-875.

Frank, A. B., Berdahl, J. D., Hanson, J. D., Liebig, M. A., and Johnson, H. A. 2004. Biomass and carbon partitioning in switchgrass. Crop Sci. 44: 1391-1396.

Frank, J. R., Brown, T. R., Volk, T. A., Heavey, J. P., and Malmsheimer, R. W. 2018. A stochastic techno-economic analysis of shrub willow production using EcoWillow 3.0S. Biofuels Bioprod. Biorefin. 12:846-856.

Gagne-Bourgue, F., Aliferis, K. A., Seguin, P., Rani, M., Samson, R., and Jabaji, S. 2013. Isolation and characterization of indigenous endophytic bacteria associated with leaves of switchgrass (Panicum virgatum L.) cultivars. J. Appl. Microbiol. 114:836-853.

Gao, C., Montoya, L., Xu, L., Madera, M., Hollingsworth, J., Purdom, E., Singan, V., Vogel, J., Hutmacher, R. B., Dahlberg, J. A., Coleman-Derr, D., Lemaux, P. G., and Taylor, J. W. 2020. Fungal community assembly in drought-stressed sorghum shows stochasticity, selection, and universal ecological dynamics. Nat. Commun. 11:34.

Gao, J., Sasse, J., Lewald, K. M., Zhalnina, K., Cornmesser, L. T., Duncombe, T. A., Yoshikuni, Y., Vogel, J. P., Firestone, M. K., and Northen, T. R. 2018. Ecosystem fabrication (EcoFAB) protocols for the construction of laboratory ecosystems designed to study plant-microbe Interactions. JoVE J. 134:57170.

Garcia, K., and Zimmermann, S. D. 2014. The role of mycorrhizal associations in plant potassium nutrition. Front. Plant Sci. 5:337.

Gebremikael, M. T., Steel, H., Buchan, D., Bert, W., and De Neve, S. 2016. Nematodes enhance plant growth and nutrient uptake under $\mathrm{C}$ and N-rich conditions. Sci. Rep. 6:32862.

Geisen, S., Mitchell, E. A. D., Adl, S., Bonkowski, M., Dunthorn, M., Flemming, E., Fernández, L. D., Jousset, A., Krashevska, V., Singer, D., Spiegel, F. W., Walochnik, J., and Lara, E. 2018. Soil protists: A fertile frontier in soil biology research. FEMS Microbiol. Rev. 42:293-323.
Gelfand, I., Sahajpal, R., Zhang, X., Izaurralde, R. C., Gross, K. L., and Robertson, P. G. 2013. Sustainable bioenergy production from marginal lands in the US Midwest. Nature 493:514-517.

Ghimire, S. R., Charlton, N. D., Bell, J. D., Krishnamurthy, Y. L., and Craven, K. D. 2010. Biodiversity of fungal endophyte communities inhabiting switchgrass (Panicum virgatum L.) growing in the native tallgrass prairie of northern Oklahoma. Fungal Divers. 47:19-27.

Ghimire, S. R., and Craven, K. D. 2011. Enhancement of switchgrass (Panicum virgatum $\mathrm{L}$.) biomass production under drought conditions by the ectomycorrhizal fungus Sebacina vermifera. Appl. Environ. Microbiol. 77:7063-7067.

Giauque, H., Connor, E. W., and Hawkes, C. V. 2018. Endophyte traits relevant to stress tolerance, resource use and habitat of origin predict effects on host plants. New Phytol. 221:2239-2249.

Giauque, H., and Hawkes, C. V. 2013. Climate affects symbiotic fungal endophyte diversity and performance. Am. J. Bot. 100:1435-1444.

Göller, P. C., Haro-Moreno, J. M., Rodriguez-Valera, F., Loessner, M. J., and Gómez-Sanz, E. 2020. Uncovering a hidden diversity: Optimized protocols for the extraction of dsDNA bacteriophages from soil. Microbiome 8:17.

Grady, K. L., Sorensen, J. W., Stopnisek, N., Guittar, J., and Shade, A. 2019. Assembly and seasonality of core phyllosphere microbiota on perennial biofuel crops. Nat. Commun. 10:4135.

Grossmann, G., Guo, W. J., Ehrhardt, D. W., Frommer, W. B., Sit, R. V., Quake, S. R., and Meier, M. 2011. The RootChip: An integrated microfluidic chip for plant science. Plant Cell 23:4234-4240.

Henkes, G. J., Kandeler, E., Marhan, S., Scheu, S., and Bonkowski, M. 2018. Interactions of mycorrhiza and protists in the rhizosphere systemically alter microbial community composition, plant shoot-to-root ratio and within-root system nitrogen allocation. Front. Environ. Sci. 6:117.

Henning, J. A., Weston, D. J., Pelletier, D. A., Timm, C. M., Jawdy, S. S., and Classen, A. T. 2016. Root bacterial endophytes alter plant phenotype, but not physiology. PeerJ 4:e2606.

Henning, J. A., Weston, D. J., Pelletier, D. A., Timm, C. M., Jawdy, S. S., and Classen, A. T. 2019. Relatively rare root endophytic bacteria drive plant resource allocation patterns and tissue nutrient concentration in unpredictable ways. Am. J. Bot. 106:1423-1434.

Hestrin, R., Lee, M. R., Whitaker, B. K., and Pett-Ridge, J. 2021. The switchgrass microbiome: A review of structure, function, and taxonomic distribution. Phytobiomes J. 5:14-28.

Hetrick, B. A. D., Kitt, D. G., and Wilson, G. T. 1988. Mycorrhizal dependence and growth habit of warm-season and cool-season tallgrass prairie plants. Can. J. Bot. 66:1376-1380.

Johnke, J., Baron, M., de Leeuw, M., Kushmaro, A., Jurkevitch, E., Harms, H., and Chatzinotas, A. 2017. A generalist protist predator enables coexistence in multitrophic predator-prey systems containing a phage and the bacterial predator Bdellovibrio. Front. Ecol. Evol. 5:124.

Kakouridis, A., Hagen, J. A., Kan, M. P., Mambelli, S., Feldman, L. J., Herman, D. J., Pett-Ridge, J., and Firestone, M. K. 2020. Routes to roots: Direct evidence of water transport by arbuscular mycorrhizal fungi to host plants. bioRxiv.

Kehe, J., Kulesa, A., Ortiz, A., Ackerman, C. M., Thakku, S. G., Sellers, D., Kuehn, S., Gore, J., Friedman, J., and Blainey, P. C. 2019. Massively parallel screening of synthetic microbial communities. Proc. Natl. Acad. Sci. U.S.A. 116:12804-12809.

Ker, K., Seguin, P., Driscoll, B. T., Fyles, J. W., and Smith, D. L. 2012. Switchgrass establishment and seeding year production can be improved by inoculation with rhizosphere endophytes. Biomass Bioenergy 47: 295-301.

Kim, S., Lowman, S., Hou, G., Nowak, J., Flinn, B., and Mei, C. 2012. Growth promotion and colonization of switchgrass (Panicum virgatum) cv. Alamo by bacterial endophyte Burkholderia phytofirmans strain PsJN. Biotechnol. Biofuels 5:37.

Kirchhof, G., Eckert, B., Stoffels, M., Baldani, J. I., Reis, V. M., and Hartmann, A. 2001. Herbaspirillum frisingense sp. nov., a new nitrogen-fixing bacterial species that occurs in C4-fibre plants. Int. J. Syst. Evol. Microbiol. 51: 157-168.

Kleczewski, N. M., Bauer, J. T., Bever, J. D., Clay, K., and Reynolds, H. L. 2012. A survey of endophytic fungi of switchgrass (Panicum virgatum) in the Midwest, and their putative roles in plant growth. Fungal Ecol. 5:521-529.

Knoth, J. L., Kim, S.-H., Ettl, G. J., and Doty, S. L. 2014. Biological nitrogen fixation and biomass accumulation within poplar clones as a result of inoculations with diazotrophic endophyte consortia. New Phytol. 201:599-609. 
Lee, M. R., and Hawkes, C. V. 2021. Plant and soil drivers of whole-plant microbiomes: Variation in switchgrass fungi from coastal to mountain sites. Phytobiomes J. 5:69-79.

Leopold, D. R., and Busby, P. E. 2020. Host genotype and colonist arrival order jointly govern plant microbiome composition and function. Curr. Biol. 30: 3260-3266.e5.

Li, D., Voigt, T. B., and Kent, A. D. 2015. Plant and soil effects on bacterial communities associated with Miscanthus $\times$ giganteus rhizosphere and rhizomes. Glob. Change Biol. Bioenergy 8:183-193.

Ma, L., Rocha, F. I., Lee, J., Choi, J., Tejera, M., Sooksa-Nguan, T., Boersma, N. N., Vanloocke, A., Heaton, E., and Howe, A. 2021. The impact of stand age and fertilization on the soil microbiome of Miscanthus $\times$ giganteus. Phytobiomes J. 5:51-59.

Mandyam, K., Fox, C., and Jumpponen, A. 2011. Septate endophyte colonization and host responses of grasses and forbs native to a tallgrass prairie. Mycorrhiza 22:109-119.

Mao, Y., Li, X., Smyth, E. M., Yannarell, A. C., and Mackie, R. I. 2014. Enrichment of specific bacterial and eukaryotic microbes in the rhizosphere of switchgrass (Panicum virgatum L.) through root exudates. Environ. Microbiol. Rep. 6:293-306.

Martin, F., Tuskan, G. A., DiFazio, S. P., Lammers, P., Newcombe, G., and Podila, G. K. 2004. Symbiotic sequencing for the Populus mesocosm. New Phytol. 161:330-335.

Martin, F. M., Uroz, S., and Barker, D. G. 2017. Ancestral alliances: Plant mutualistic symbioses with fungi and bacteria. Science 356:eaad4501.

Massalha, H., Korenblum, E., Malitsky, S., Shapiro, O. H., and Aharoni, A. 2017. Live imaging of root-bacteria interactions in a microfluidics setup. Proc. Natl. Acad. Sci. U.S.A. 114:4549-4554.

Mau, R. L., Liu, C. M., Aziz, M., Schwartz, E., Dijkstra, P., Marks, J. C., Price, L. B., Keim, P., and Hungate, B. A. 2015. Linking soil bacterial biodiversity and soil carbon stability. ISME J. 9:1477-1480.

McFadden, G. I. 2001. Primary and secondary endosymbiosis and the origin of plastids. J. Phycol. 37:951-959.

Mendes, R., Kruijt, M., de Bruijn, I., Dekkers, E., van der Voort, M., Schneider, J. H. M., Piceno, Y. M., DeSantis, T. Z., Andersen, G. L., Bakker, P. A. H. M., and Raaijmakers, J. M. 2011. Deciphering the rhizosphere microbiome for disease-suppressive bacteria. Science 332:1097-1100.

Moffitt, J. R., Hao, J., Bambah-Mukku, D., Lu, T., Dulac, C., and Zhuang, X. 2016. High-performance multiplexed fluorescence in situ hybridization in culture and tissue with matrix imprinting and clearing. Proc. Natl. Acad. Sci. U.S.A. 113:14456-14461.

Nelson, M., Gray, K., and Allen, J. P. 2015. Group dynamics challenges: Insights from Biosphere 2 experiments. Life Sci. Space Res. (Amst.) 6:79-86.

Nuccio, E. E., Starr, E., Karaoz, U., Brodie, E. L., Zhou, J., Tringe, S. G., Malmstrom, R. R., Woyke, T., Banfield, J. F., Firestone, M. K., and PettRidge, J. 2020. Niche differentiation is spatially and temporally regulated in the rhizosphere. ISME J. 14:999-1014.

Oburger, E., and Jones, D. L. 2018. Sampling root exudates-Mission impossible? Rhizosphere 6:116-133.

Oburger, E., and Schmidt, H. 2016. New methods to unravel rhizosphere processes. Trends Plant Sci. 21:243-255.

Örmälä-Odegrip, A.-M., Ojala, V., Hiltunen, T., Zhang, J., Bamford, J. K. H., and Laakso, J. 2015. Protist predation can select for bacteria with lowered susceptibility to infection by lytic phages. BMC Evol. Biol. 15:81-87.

Pawar, P. M.-A., Schnürer, A., Mellerowicz, E. J., and Rönnberg-Wästljung, A. C. 2018. QTL mapping of wood FT-IR chemotypes shows promise for improving biofuel potential in short rotation coppice willow (Salix spp.). Bioenerg. Res. 11:351-363.

Pett-Ridge, J., and Firestone, M. K. 2017. Using stable isotopes to explore rootmicrobe-mineral interactions in soil. Rhizosphere 3:244-253.

Pett-Ridge, J., Shi, J., Estera-Molina, K., Nuccio, E. E., Yuan, M., Rijkers, R., Swenson, T., Zhalnina, K., Northen, T., Zhou, J., and Firestone, M. K. 2021. Rhizosphere carbon turnover from cradle to grave: The role of microbe-plant interactions. Pages 51-73 in: Rhizosphere Biology: Interactions Between Microbes and Plants. Rhizosphere Biology. V. V. S. R. Gupta and A. K. Sharma, eds. Springer, Singapore.

Ray, P., Abraham, P. E., Guo, Y., Giannone, R. J., Engle, N. L., Yang, Z. K., Jacobson, D., Hettich, R. L., Tschaplinski, T. J., and Craven, K. D. 2019. Scavenging organic nitrogen and remodelling lipid metabolism are key survival strategies adopted by the endophytic fungi, Serendipita vermifera and Serendipita bescii to alleviate nitrogen and phosphorous starvation in vitro. Environ. Microbiol. Rep. 11:548-557.
Ray, P., and Craven, K. D. 2016. Sebacina vermifera: A unique root symbiont with vast agronomic potential. World J. Microbiol. Biotechnol. 32:16.

Remke, M. J., Johnson, N. C., Wright, J., Williamson, M., and Bowker, M. A. 2020. Sympatric pairings of dryland grass populations, mycorrhizal fungi and associated soil biota enhance mutualism and ameliorate drought stress. J. Ecol. doi:10.1111/1365-2745.13546

Revillini, D., Wilson, G. W. T., Miller, R. M., Lancione, R., and Johnson, N. C. 2019. Plant diversity and fertilizer management shape the belowground microbiome of native grass bioenergy feedstocks. Front. Plant Sci. 10:1018.

Robertson, G. P., Hamilton, S. K., Barham, B. L., Dale, B. E., Izaurralde, R. C., Jackson, R. D., Landis, D. A., Swinton, S. M., Thelen, K. D., and Tiedje, J. M. 2017. Cellulosic biofuel contributions to a sustainable energy future: Choices and outcomes. Science 356:eaal2324.

Robertson, G. P., Paul, E., and Harwood, R. 2000. Greenhouse gases in intensive agriculture: Contributions of individual gases to the radiative forcing of the atmosphere. Science 289:1922-1925.

Robins, J. G. 2012. Variation within accessions of switchgrass germplasm for dry matter yield and forage quality in a semiarid environment. Crop Sci. 52: 2253-2261.

Rodrigues, R. R., Moon, J., Zhao, B., and Williams, M. A. 2016. Microbial communities and diazotrophic activity differ in the root-zone of Alamo and Dacotah switchgrass feedstocks. Glob. Change Biol. Bioenergy 9: 1057-1070.

Roley, S. S., Duncan, D. S., Liang, D., Garoutte, A., Jackson, R. D., Tiedje, J. M., and Robertson, P. G. 2018. Associative nitrogen fixation (ANF) in switchgrass (Panicum virgatum) across a nitrogen input gradient. PLoS One 13:e0197320.

Roley, S. S., Ulbrich, T. C., and Robertson, G. P. 2021. Nitrogen fixation and resorption efficiency differences among twelve upland and lowland switchgrass cultivars. Phytobiomes J. 5:97-107.

Roley, S. S., Xue, C., Hamilton, S. K., Tiedje, J. M., and Robertson, P. G. 2019. Isotopic evidence for episodic nitrogen fixation in switchgrass (Panicum virgatum L.). Soil Biol. Biochem. 129:90-98.

Roozeboom, K. L., Wang, D., McGowan, A. R., Propheter, J. L., Staggenborg, S. A., and Rice, C. W. 2019. Long-term biomass and potential ethanol yields of annual and perennial biofuel crops. Agron. J. 111:74-83.

Rubin, B. E., Diamond, S., Cress, B. F., Crits-Christoph, A., He, C., Xu, M., Zhou, Z., Smock, D. C., Tang, K., Owens, T. K., Krishnappa, N., Sachdeva, R., Deutschbauer, A. M., Banfield, J. F., and Doudna, J. A. 2020. Targeted genome editing of bacteria within microbial communities. bioRxiv.

Sanderman, J., Hengl, T., and Fiske, G. J. 2017. Soil carbon debt of 12,000 years of human land use. Proc. Natl. Acad. Sci. U.S.A. 114:9575-9580.

Sanderson, M. A., and Adler, P. R. 2008. Perennial forages as second generation bioenergy crops. Int. J. Mol. Sci. 9:768-788.

Sanderson, M. A., Reed, R. L., McLaughlin, S. B., Wullschleger, S. D., Conger, B. V., Parrish, D. J., Wolf, D. D., Taliaferro, C., Hopkins, A. A., Ocumpaugh, W. R., and Hussey, M. A. 1996. Switchgrass as a sustainable bioenergy crop. Bioresour. Technol. 56:83-93.

Sarkar, A., Asaeda, T., Wang, Q., and Rashid, Md. H. 2015. Arbuscular mycorrhizal influences on growth, nutrient uptake, and use efficiency of Miscanthus sacchariflorus growing on nutrient-deficient river bank soil. Flora 212:46-54

Sawyer, A., Staley, C., Lamb, J., Sheaffer, C., Kaiser, T., Gutknecht, J., Sadowsky, M. J., and Rosen, C. 2019. Cultivar and phosphorus effects on switchgrass yield and rhizosphere microbial diversity. Appl. Microbiol. Biotechnol. 103:1973-1987.

Schmidt, J. E., Kent, A. D., Brisson, V. L., and Gaudin, A. C. M. 2019. Agricultural management and plant selection interactively affect rhizosphere microbial community structure and nitrogen cycling. Microbiome 7:146

Shade, A., and Stopnisek, N. 2019. Abundance-occupancy distributions to prioritize plant core microbiome membership. Curr. Opin. Microbiol. 49:50-58.

Sharma, S., Gaur, R., and Choudhary, D. K. 2013. Solubilization of inorganic phosphate (P-i) and plant growth-promotion (PGP) activities by root-nodule bacteria isolated from cultivated legume, mothbean (Vigna aconitifolia L.) of the Great Indian Thar desert. Res. J. Biotechnol. 8:4-10.

Shcherbak, I., Millar, N., and Robertson, P. G. 2014. Global metaanalysis of the nonlinear response of soil nitrous oxide $\left(\mathrm{N}_{2} \mathrm{O}\right)$ emissions to fertilizer nitrogen. Proc. Natl. Acad. Sci. U.S.A. 111:9199-9204.

Shelake, R. M., Pramanik, D., and Kim, J.-Y. 2019. Exploration of plantmicrobe interactions for sustainable agriculture in CRISPR Era. Microorganisms 7:269. 
Shen, J., Yuan, L., Zhang, J., Li, H., Bai, Z., Chen, X., Zhang, W., and Zhang, F. 2011. Phosphorus dynamics: From soil to plant. Plant Physiol. 156:997-1005.

Sher, S., Baker, N. R., Herman, D., Fossum, C., Hale, L., Zhang, X., Nuccio, E., Saha, M., Zhou, J., Pett-Ridge, J., and Firestone, M. 2020. Microbial extracellular polysaccharide production and aggregate stability controlled by switchgrass (Panicum virgatum) root biomass and soil water potential. Soil Biol. Biochem. 143:107742.

Singer, E., Bonnette, J., Kenaley, S. C., Woyke, T., and Juenger, T. E. 2019a. Plant compartment and genetic variation drive microbiome composition in switchgrass roots. Environ. Microbiol. Rep. 11:185-195.

Singer, E., Bonnette, J., Woyke, T., and Juenger, T. E. 2019b. Conservation of endophyte bacterial community structure across two panicum grass species. Front. Microbiol. 10:2181.

Slessarev, E. W., Nuccio, E. E., McFarlane, K. J., Ramon, C. E., Saha, M., Firestone, M. K., and Pett-Ridge, J. 2020. Quantifying the effects of switchgrass (Panicum virgatum) on deep organic C stocks using natural abundance $14 \mathrm{C}$ in three marginal soils. Glob. Change Biol. Bioenergy 12: 834-847.

Smercina, D. N., Bowsher, A. W., Evans, S. E., Friesen, M. L., Eder, E. K., Hoyt, D. W., and Tiemann, L. K. 2021. Switchgrass rhizosphere metabolite chemistry driven by nitrogen availability. Phytobiomes J. 5:88-96.

Smercina, D. N., Evans, S. E., Friesen, M. L., and Tiemann, L. K. 2019. To fix or not to fix: Controls on free-living nitrogen fixation in the rhizosphere. Appl. Environ. Microbiol. 85:e02546-18.

Soman, C., Keymer, D. P., and Kent, A. D. 2018. Edaphic correlates of feedstock-associated diazotroph communities. Glob. Change Biol. Bioenergy 10:343-352.

Stanton, B. J., Bourque, A., Coleman, M., Eisenbies, M., Emerson, R. M., Espinoza, J., Gantz, C., Himes, A., Rodstrom, A., Shuren, R., Stonex, R., Volk, T., and Zerpa, J. 2020. The practice and economics of hybrid poplar biomass production for biofuels and bioproducts in the Pacific Northwest. Bioenerg. Res. 102:1-18.

Starr, E. P., Nuccio, E. E., Pett-Ridge, J., Banfield, J. F., and Firestone, M. K. 2019. Metatranscriptomic reconstruction reveals RNA viruses with the potential to shape carbon cycling in soil. Proc. Natl. Acad. Sci. U.S.A. 116: 25900-25908.

Stoof, C. R., Richards, B. K., Woodbury, P. B., Fabio, E. S., Brumbach, A. R., Cherney, J., Das, S., Geohring, L., Hansen, J., Hornesky, J., Mayton, H., Mason, C., Ruestow, G., Smart, L. B., Volk, T. A., and Steenhuis, T. S. 2014. Untapped potential: Opportunities and challenges for sustainable bioenergy production from marginal lands in the Northeast USA. Bioenerg. Res. 8: 482-501.

Straub, D., Yang, H., Liu, Y., Tsap, T., and Ludewig, U. 2013. Root ethylene signalling is involved in Miscanthus sinensis growth promotion by the bacterial endophyte Herbaspirillum frisingense GSF30(T). J. Exp. Bot. 64: 4603-4615.

Tilman, D., Hill, J., and Lehman, C. 2006. Carbon-negative biofuels from lowinput high-diversity grassland biomass. Science 314:1598-1600.

Timm, C. M., Campbell, A. G., Utturkar, S. M., and Jun, S. R. 2015. Metabolic functions of Pseudomonas fluorescens strains from Populus deltoides depend on rhizosphere or endosphere isolation compartment. Frontiers (Boulder) 6: 1118.

Timm, C. M., Pelletier, D. A., Jawdy, S. S., Gunter, L. E., Henning, J. A., Engle, N., Aufrecht, J., Gee, E., Nookaew, I., Yang, Z., Lu, T.-Y., Tschaplinski, T. J., Doktycz, M. J., Tuskan, G. A., and Weston, D. J. 2016. Two poplarassociated bacterial isolates induce additive favorable responses in a constructed plant-microbiome system. Front. Plant Sci. 7:364.

Toro, M., Azcon, R., and Barea, J. 1997. Improvement of arbuscular mycorrhiza development by inoculation of soil with phosphate-solubilizing rhizobacteria to improve rock phosphate bioavailability ((sup32)P) and nutrient cycling. Appl. Environ. Microbiol. 63:4408-4412.

Trubl, G., Jang, H. B., Roux, S., Emerson, J. B., Solonenko, N., Vik, D. R., Solden, L., Ellenbogen, J., Runyon, A. T., Bolduc, B., Woodcroft, B. J., Saleska, S. R., Tyson, G. W., Wrighton, K. C., Sullivan, M. B., and Rich, V. I. 2018. Soil viruses are underexplored players in ecosystem carbon processing. mSystems 3:e00076-18.

Ulbrich, T. C., Friesen, M., Roley, S. S., Tiemann, L. K., and Evans, S. E. 2021. Intraspecific variability in root traits and edaphic conditions influence soil microbiomes across 12 switchgrass cultivars. Phytobiomes J. 5:108-120.
US DOE. 2014. Research for sustainable bioenergy: Linking genomic and ecosystem sciences. U.S. Department of Energy Office of Science. https:// genomicscience.energy.gov/sustainability/SustainableBiofuels-HR.pdf

US DOE. 2016. 2016. Billion-ton report: Advancing domestic resources for a thriving bioeconomy. U.S. Department of Energy Office of Energy Efficiency and Renewable Energy. https://www.energy.gov/eere/ bioenergy/downloads/2016-billion-ton-report-advancing-domesticresources-thriving-bioeconomy

Vaccari, D. A. 2009. Phosphorus: A looming crisis. Sci. Am. 300:54-59.

Vance, C. P., Uhde-Stone, C., and Allan, D. L. 2003. Phosphorus acquisition and use: Critical adaptations by plants for securing a nonrenewable resource. New Phytol. 157:423-447.

Vanderkelen, I., Zscheischler, J., Gudmundsson, L., Keuler, K., Rineau, F., Beenaerts, N., Vangronsveld, J., Vicca, S., and Thiery, W. 2020. A novel method for assessing climate change impacts in ecotron experiments. Int. J. Biometeorol. 64:1709-1727.

Vieira, S., Sikorski, J., Dietz, S., Herz, K., Schrumpf, M., Bruelheide, H., Scheel, D., Friedrich, M. W., and Overmann, J. 2019. Drivers of the composition of active rhizosphere bacterial communities in temperate grasslands. ISME J. 14: 463-475.

Wallenstein, M. D. 2017. Managing and manipulating the rhizosphere microbiome for plant health: A systems approach. Rhizosphere 3:230-232.

Wang, D., Lebauer, D. S., and Dietze, M. C. 2010. A quantitative review comparing the yield of switchgrass in monocultures and mixtures in relation to climate and management factors. Glob. Change Biol. Bioenergy 2:16-25.

Watterson, W. J., Tanyeri, M., Watson, A. R., Cham, C. M., Shan, Y., Chang, E. B., Eren, A. M., and Tay, S. 2020. Droplet-based high-throughput cultivation for accurate screening of antibiotic resistant gut microbes. eLife 9:e56998.

Weston, D. J., Pelletier, D. A., Morrell-Falvey, J. L., Tschaplinski, T. J., Jawdy, S. S., Lu, T.-Y., Allen, S. M., Melton, S. J., Martin, M. Z., Schadt, C. W., Karve, A. A., Chen, J.-G., Yang, X., Doktycz, M. J., and Tuskan, G. A. 2012. Pseudomonas fluorescens induces strain-dependent and strain-independent host plant responses in defense networks, primary metabolism, photosynthesis, and fitness. Mol. Plant-Microbe Interact. 25:765-778.

Whitaker, B. K., Reynolds, H. L., and Clay, K. 2018. Foliar fungal endophyte communities are structured by environment but not host ecotype in Panicum virgatum (switchgrass). Ecology 99:2703-2711.

Wipf, H., Bùi, T.-N., and Coleman-Derr, D. 2020. Distinguishing between the impacts of heat and drought stress on the root microbiome of Sorghum bicolor. Phytobiomes J. doi:10.1094/PBIOMES-07-20-0052-R

Woods, L. E., Cole, C. V., Elliott, E. T., Anderson, R. V., and Coleman, D. C. 1982. Nitrogen transformations in soil as affected by bacterial-microfaunal interactions. Soil Biol. Biochem. 14:93-98.

Xia, Y., Amna, A., and Opiyo, S. O. 2018. The culturable endophytic fungal communities of switchgrass grown on a coal-mining site and their effects on plant growth. PLoS One 13:e0198994.

Xia, Y., Greissworth, E., Mucci, C., Williams, M. A., and De Bolt, S. 2013. Characterization of culturable bacterial endophytes of switchgrass (Panicum virgatum L.) and their capacity to influence plant growth. Glob. Change Biol. Bioenergy 5:674-682.

Xiong, W., Song, Y., Yang, K., Gu, Y., Wei, Z., Kowalchuk, G. A., Xu, Y., Jousset, A., Shen, Q., and Geisen, S. 2020. Rhizosphere protists are key determinants of plant health. Microbiome 8:27.

Xu, L., Naylor, D., Dong, Z., Simmons, T., Pierroz, G., Hixson, K. K., Kim, Y.M., Zink, E. M., Engbrecht, K. M., Wang, Y., Gao, C., DeGraaf, S., Madera, M. A., Sievert, J. A., Hollingsworth, J., Birdseye, D., Scheller, H. V., Hutmacher, R., Dahlberg, J., Jansson, C., Taylor, J. W., Lemaux, P. G., and Coleman-Derr, D. 2018. Drought delays development of the sorghum root microbiome and enriches for monoderm bacteria. Proc. Natl. Acad. Sci. U.S.A. 115:E4284-E4293.

Zan, C. S., Fyles, J. W., Girouard, P., and Samson, R. A. 2001. Carbon sequestration in perennial bioenergy, annual corn and uncultivated systems in southern Quebec. Agric. Ecosyst. Environ. 86:135-144.

Zhalnina, K., Louie, K. B., Hao, Z., Mansoori, N., da Rocha, U. N., Shi, S., Cho, H., Karaoz, U., Loqué, D., Bowen, B. P., Firestone, M. K., Northen, T. R., and Brodie, E. L. 2018. Dynamic root exudate chemistry and microbial substrate preferences drive patterns in rhizosphere microbial community assembly. Nat. Microbiol. 3:470-480.

Zumkehr, A., and Campbell, J. E. 2013. Historical U.S. cropland areas and the potential for bioenergy production on abandoned croplands. Environ. Sci. Technol. 47:3840-3847. 